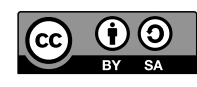

DOI: $10.4312 / \mathrm{mz} .56 .2 .85-105$

UDK 780.649(497.4):001.891"19/20"

\title{
Research on Slovenian Organs from the Beginning of the Twentieth Century to the Monograph Orgle Slovenije in 2018

\author{
Jurij Dobravec
} \\ Independent researcher
}

\begin{abstract}
The paper analyses the development of the structure and content of pipe organ catalogues that have appeared in Slovenian organology since the beginning of twentieth century. Of seventy catalogues describing multiple organs, particular attention is devoted to ten, especially the inventories of the Maribor (1911) and Ljubljana (1918) Dioceses, and the monograph Orgle Slovenije (2018).
\end{abstract}

Keywords: pipe organ, organography, catalogue, database, research history

\section{IZVLEČEK}

Članek obravnava razvoj strukture in vsebine katalogov orgel, ki se v slovenski organologiji pojavljajo od začetka 20. stoletja. Izmed sedemdesetih, v katerih je opisanih več orgel, je posebna pozornost namenjena desetim, posebej pa so izpostavljeni popisi Mariborske (1911) in Ljubljanske (1918) škofije ter delo Orgle Slovenije (2018).

Ključne besede: orgle, organografija, katalog, podatkovna zbirka, zgodovina raziskav 


\section{Introduction}

In 2002, Kerala J. Snyder mobilised his colleagues at GOArt - Göteborg Organ Art Center of the University of Gothenburg, Sweden - and published an influential work on the European pipe organ tradition, entitled The Organ as a Mirror of Its Time. ${ }^{1}$ Following this, many other studies summarised the organ as an instrument integrated into Western Christianity and its various cultural landscapes, standing today as a reflection of contemporary trends in design, engineering, acoustics and music. Above all, music personifies the spirit of composers and performers.

Along with describing the organ's millennial development and the standards often prescribed to musicians by Church authorities, organology considers individual instruments as unique and tightly intertwined with the characteristics of the room in which they are installed. The uniqueness, dimensions, complexity and immanent sound diversity of organs initiate many questions uncommon in the research of other, movable musical instruments.

The majority of investigations into the organ, and consequently related research papers, fit into one of three categories:

1. analyses of individual instruments,

2. overviews of organ workshops or style schools,

3. surveys of selected organ landscapes over time.

The result of most research generally comprises two core parts: analysis and synthesis, sometimes accompanied by application. Table 1 shows the typical elements of organ research. There may be some overlap between categories, primarily due to the individualised ordering of the organs, the specific characteristics of the interior, or the wishes of a sponsoring patron.

The present paper introduces the third category of research, focusing on organ landscape catalogues and statistics derived from previously surveyed data. The word statistics in this text does not apply to inferential statistical analyses in the mathematical sense, but rather to the syntheses that authors have shown as a result of their surveys, mostly counting and cataloguing. The list of the catalogues presented is limited to those that do not operate with statistical samples, but incorporate the entire population of instruments in the selected stylistic area or workshop.

Through comparisons, the results will show:

- the extent to which the authors implemented various metadata summary lists, maps and similar research methods;

1 Kerala J. Snyder, ed., The Organ as a Mirror of Its Time (Oxford: Oxford University Press, 2002). 
- how the methods of data treatment were changed and upgraded throughout the century;

- the deficiencies of existing databases, representing risks of which future users should be aware;

- the advantages of the existing catalogues for future research.

The paper consequently opens up the possibility of comparing Slovenian landscape organology with the situation abroad.

Table 1: Elements of organ research

\begin{tabular}{llll} 
& analysis & synthesis & application \\
\hline \multirow{2}{*}{1 (instrument) } & $\begin{array}{l}\text { technical, } \\
\text { acoustic, } \\
\text { artistic }\end{array}$ & $\begin{array}{l}\text { (depends on the } \\
\text { purpose) }\end{array}$ & $\begin{array}{l}\text { (historically) informed } \\
\text { performance, } \\
\text { restoration, } \\
\text { renovation, } \\
\text { reconstruction }\end{array}$ \\
\hline $\begin{array}{l}\text { 2 (organ } \\
\text { workshop) }\end{array}$ & $\begin{array}{l}\text { sequence of opuses, } \\
\text { development and } \\
\text { its orientations, } \\
\text { typology }\end{array}$ & $\begin{array}{l}\text { interrelations, } \\
\text { style dependence, } \\
\text { relations to } \\
\text { composers and } \\
\text { performers }\end{array}$ & $\begin{array}{l}\text { style authenticity, } \\
\text { performance possibilities }\end{array}$ \\
\hline 3 (landscape) & $\begin{array}{l}\text { time- and } \\
\text { place-oriented } \\
\text { catalogue with } \\
\text { descriptions of } \\
\text { separate elements } \\
\text { (technical, acoustic, } \\
\text { artistic, etc.) }\end{array}$ & $\begin{array}{l}\text { statistics, } \\
\text { style dependence, } \\
\text { integration into } \\
\text { the cultural } \\
\text { and social } \\
\text { environment }\end{array}$ & $\begin{array}{l}\text { performance practice } \\
\text { through time, } \\
\text { presentation and museums, } \\
\text { comparative evaluation, } \\
\text { heritage preservation and } \\
\text { protection }\end{array}$ \\
\hline
\end{tabular}

\section{Pipe organ catalogues and databases}

Where they exist, pipe organ catalogues represent an appreciated induction for the detailed study of organ landscapes. From their substance, users can obtain a general overview of the area or workshop, distil the particularities, gain a sense of biases and possibilities, and specify the goals of their own research. The introductions to the catalogues, which outline the sociohistorical circumstances, reveal a broader insight into the subject to scholars, raising more complex questions and initiating comparisons. With the inclusion of photographs, many catalogues not only attract a lay audience, thereby promoting the complex phenomenon of the organ, but also serve art historians and others for comparisons of design and style.

Regarding the catalogues available in bookshops, the researcher should pay special attention to popular books of organs. Although sometimes appearing 
exhaustive, they often only gather the representative instruments of a particular area. For example, the otherwise splendid seminal book Orgle na Slovenskem (Pipe Organs in Slovenia), ${ }^{2}$ could mislead the user into believing that it speaks of all of the organs in the country, whereas the authors only selected a "representative" tenth part of the existing organs of the time. In similar works known around the world, the word "representative" typically reveals the authors' preference.

Here we define a catalogue as an inventory expanded with selected details, short descriptions and supplements, and sometimes also photographic, video and audio recordings. By definition, the inventory lists all existent (or accessible) objects. As an upgrade, the usefulness of the catalogue depends on the survey methods and the aim. Above all, it depends on the number of details, with their quality demonstrating the author's efforts. Performers usually expect details such as the number of manuals and the keyboard compass, the location of the console including its orientation in the room, a concise description, and the disposition of the stops with their sonic characteristics.

In the 1970s, pipe organ data started their migration to computers, ${ }^{3}$ and in the last two decades, all cataloguing has taken place digitally. Computerbased systems make expanded data easily available; for example, audio and video recordings, links to the web content and background sources. Computer software enables interconnections, comprehensive analyses and innovative solutions for the presentation and promotion of organs, especially on the internet. The hierarchical structure of a database with well-established metadata description ${ }^{4}$ can simplify the working process and allow scientists to focus onto specific goals, modern methods and syntheses with practical applications.

\section{Catalogues listing Slovenian organs}

The surprising number of catalogues with Slovenian organs indicates the high level of enthusiasm of scholars and other researchers. The appended table lists seventy such catalogues. With a few exceptions, those selected for treatment in the present paper contain descriptions of ten or more organs. Besides those listed, we know of a dozen or so smaller reports about fewer organs within an individual parish or municipality, made by smaller workshops or used by the same organisation.

As a rule, the listed catalogues deal with instruments made, for instance, by a particular organ workshop for the churches of a Catholic diocese or

2 Milko Bizjak and Edo Škulj, Orgle na Slovenskem (Ljubljana: Državna založba Slovenije, 1985). English translation as Pipe Organs in Slovenia (Ljubljana: Državna založba Slovenije, 1987).

3 Uwe Pape, “Orgeldatenbank," Ars Organi 34 (1986): 22-29.

4 Jurij Dobravec, "Presečni arhiv in zbirka podatkov o slovenskih orglah ARSORS," Arhivi 39, no. 2 (2016): 263-275. 
deanery, or within a selected administrative district. Most of the catalogues meet the aforementioned criteria. A series of books by Edo Škulj describing the opuses of organ building workshops include instruments installed abroad by Slovenian masters. We have intentionally appended a few shorter catalogues of organs made by builders who are members of what are now the Slovenian minorities in Austria in Italy, or organs bought for or by parishes of Slovenian diaspora worldwide.

We consider all of the listed contributions as valuable in shedding light on Slovenian organ history. However, some of them represent added value for their volume and methods, as well as for their clear influence on national organology and their possible importance for the professional audience. Short descriptions follow.

\subsection{Orgle v cerkvah Lavantinske škofje (Organs of the Diocese of Lavant) (1911)}

The See of the Diocese of Lavant in Maribor, which now spans across Northeastern Slovenia, initiated an extensive inventory of works of art at the beginning of the twentieth century, in which the churches of the subordinate parishes were explored. As reported by Podstenšek, ${ }^{5}$ an organ survey commenced in 1909, resulting in a report published in 1911. There are two statistics appended to the catalogue: an index of organ builders (pp. 76-77) and a short register of historical instruments (pp. 77-78). Unfortunately, we do not know further details about the methods, organisation and participants of the project.

\subsection{Statistika orgelj v ljubljanski škofiji (Statistics of Organs in the Diocese of Ljubljana) (1918-1920; 1923)}

After the Maribor precedent, Stanko Premrl, regens chori of the Ljubljana cathedral, prominent composer and author of the Slovenian national anthem, initiated a similar project for the Ljubljana Diocese covering the then Carniola province, which is today central Slovenia. After calls published in the professional bulletin for church musicians, Cerkveni glasbenik, and the Official Gazette of the diocese, ${ }^{6}$ participants from parishes reported the details of their organs and organists. Again, the variability of the extant letters shows that reporters loosely followed otherwise clear instructions. From the collected letters, Premrl composed a spreadsheet preserved in his legacy. ${ }^{7}$ Cerkveni glasbenik published the results in five parts during the First World War.

5 Matej Podstenšek, “Ob 100-letnici knjižice Orgle v cerkvah Lavantinske škofije," Cerkveni glasbenik 104, no. 6 (2011): 11.

6 Ljubljanski škofijski list 103 (1913): 128.

7 Edo Škulj, "Stoletnica Premrlove Statistike o orglah v ljubljanski škofiji," Cerkveni glasbenik 110, no. 4 (2017): 16. 
The concise writing reveals that in addition to the table, Premrl must have used a catalogue with arranged details for each organ. The final part of the article, published in 1923 with comprehensive statistics and details, demonstrates his professional approach and indicates the background of a pool of data not preserved in the hand-written field reports or his table. Premrl's scientific paper also includes a report on the projects of Slovenian organ builders between 1891 and 1916. The frequent references to both catalogues in the later organological literature demonstrates their importance.

\subsection{First War Requisition Lists of the Austro-Hungarian Lands (archive for Carniola, Styria and Littoral, 1917)}

The War Requirement Acts of the Austro-Hungarian authorities in the First World War directed the dispossession of goods and their supply for military needs. The requisition of non-ferrous metals, including organ pipes, commenced in 1917 based on previously prepared lists of organs and their characteristics. ${ }^{8}$ In addition to information about the amounts of alloy, the survey required data on historical value, possibly enabling some instruments to be exempt from this war devastation. Notwithstanding the unfortunate story for the instruments and their listeners, the well-structured general list and some particularities of artificial value today serve as a reliable reference for organology research.

\subsection{Orgle Ljubljanske nadškofije, osnovni podatki in dispozicije (Pipe Organs in the Diocese of Ljubljana with their Key Characteristics and Dispositions) (1987)}

In 1985, musicologist Dr Edo Škulj, who later served as a university professor and honourable canon of the Ljubljana Diocese, initiated the first systematic field survey of organs in a broad region of Slovenia: the country's central region, which coincides with the Ljubljana Diocese. One by one, he visited parishes and investigated instruments, particularly their sonic characters expressed in the stop dispositions. Of special value is the fact that he also listed the churches without an organ, which enabled future research to be more concentrated. The onset of the era of the personal computer and the migration of surveyed data to machines enabled the author basic digital statistics, such as simplified sorting of instruments by builders, size and year of installation. Škulj summarised the catalogue with a critical scientific review, while the database served for his later activities, particularly for his 20 books and more than 600 professional articles on Slovenian organs.

$8 \quad$ Jurij Dobravec, “Usoda slovenskih orgel v prvi svetovni vojni,” Arbivi 41 (2017): 418. 


\subsection{Card Catalogue in the INDOK Information Centre of the Ministry of Culture}

Unknown author(s), most likely working between 1985 and 1987, prepared a catalogue of organs with fundamental information typewritten on A6-format library catalogue cards. The 910 locations in this poorly documented but rather well-structured database encompass 897 existing instruments and 23 records of removed instruments. The majority of the data refers to the aforementioned Lavant and Premrl surveys, as well as the popular book Orgle na Slovenskem. No metadata, statistics or summary is known. The institute Ars organi Sloveniae voluntarily digitised the cards in 2013.

\subsection{Organs by the Deaneries of the Maribor Diocese (1993)}

Marjan Rola first became enthusiastic about organs as a theology student. His thorough research of organs in the Maribor Deanery is summarised in his graduation thesis of 1989. ' Soon after, following Škulj's standards implemented in the nearby Ljubljana Diocese, Rola investigated churches with organs in the Maribor Diocese (the Diocese of Lavant) between 1990 and 1994, publishing the findings as a series of articles in the journal Cerkveni glasbenik. The catalogue comprises certain typical data on organs, including disposition, as well as some photographs. Organology considers his portrayals of organs as being of particular historical importance, as many instruments in the area were replaced in the decades after his investigation.

\subsection{Stop Dispositions of Organs in the Koper Diocese (after 1995)}

Vladimir Pirih, head of the Commission for Church Music in the Koper Diocese, prepared an inventory of organs, which primarily served the internal needs of Church authorities and his own research. As well as disposition, year of installation and builder, Pirih also noted manual and pedal compasses.

\subsection{The ARSORS Database System by the Institute Ars organi Sloveniae (since 2005)}

Jarina Bohinj is a non-profit organisation recognised by the Ministry of Culture as an organisation in the public interest in culture. The association reorganised its structure in 2005 by establishing the institute Ars organi Sloveniae. Its goal is to research and promote the pipe organ. In the same year, the institute initiated a database with the acronym ARSORS, structured in a threelevel system. The bottom level is a digital archive of all of the available information on Slovenian organs. Approximately 24,000 documents and references

9 Marijan Rola, "Orgle v mariborski dekaniji” (Bachelor's thesis, Ljubljana Faculty of Theology, Maribor department, 1989). 
were inspected in various archives and digitised for the institute's internal usage. An associated image library gathered over 50,000 photographs, hundreds of which are of historical value, while the sound archive holds recordings of nearly 300 organs.

On the second level, a relational database in MS-Access represents the core analytical tool, comprising 65 parameters concerning each instrument. As of 2020, this part holds 2,900 records of various data on existing and past organs installed in Slovenia or made by Slovenian masters. The easily accessible data and sources in digital storage enable the comprehensive examinations necessary for management and heritage planning. In addition to extensive investigations, the dynamic data system also allows greater efficiency in the decision-making process. The top level of the system is publicly accessible on the institute's website as an interactive data table and a map with state-ofthe-art organisation.

\subsection{Organs and Organ Music in Slovenian Cultural History until the Cecilian Movement (2015)}

This doctoral dissertation by Katarina Trček explores the history of organ building in Slovenia in the period from the first half of the fifteenth century to the second half of the nineteenth century. Based on a list of organs published on the ARSORS website, ${ }^{10}$ the author expanded the previously available data with newly prepared brief descriptions of 772 historical organs, of which over 300 are still extant. She examined a number of these instruments during her field investigations. Despite using the methods of making tables known from Premrl and Škulj, the lists of instruments at the beginning of the separate chapters do not serve as statistics, but rather as kind of indexes. The Geography Institute of the Slovenian Academy of Science and Art prepared a map for the public presentation of the thesis; however, this map does not seem to be available publicly. Other summary chapters show the dynamics of organ building activities by decades, as well as the timeline of builders and the intensity of their productivity.

\subsection{Orgle Slovenije (Pipe Organs of Slovenia) (2018)}

In 2018, when European citizens were celebrating the year of cultural heritage, the institute Ars organi Sloveniae contributed a monumental national milestone, a comprehensive presentation of all existing organs in Slovenia. $\mathrm{Au}-$ thors Edo Škulj and Jurij Dobravec realised the idea in two ways: firstly in the form of a conventional book, and secondly as supplements on the internet that develop our ideas into the future. The project not only summarises current

10 Katarina Trček Marušič, "Orgle in orgelska glasba v slovenski kulturni zgodovini do nastopa cecilijanstva” (Doctoral dissertation, University of Ljubljana, 2015), 14. 
knowledge, but also bridges gaps, thus acting as a source for comparative investigations at the national and international level. After a historical overview, the core part of the book follows, in which we present an inventory of 1,094 instruments. The authors compiled the entire list of existing organs within the state borders, only omitting images and owners' personal data for some instruments installed in private residences.

Each publicly accessible site with an organ installed is presented with a short text and a graphic portrayal, as well as data such as the name of the builder, the year of installation, the historical importance and recent usage of the instrument, the size of the console, and the stop list. The national organ database ARSORS served as a principal source. The main images, taken over a three-year period, offer the observer a direct impression of organs rarely experienced. In the text description, we summarise interesting facts about the location and its history, and about the organ builder and the organ itself. In addition to being precise and supported with technical facts re-examined on site during the field survey, we use popular language in this part to address the lay public and younger readers.

What is innovative about this project is the linking of the book with internet content (Figure 1), which is made accessible either through a QR code or a URL address (Figure 1: 1,2,7,8), both indicated in the book beside each
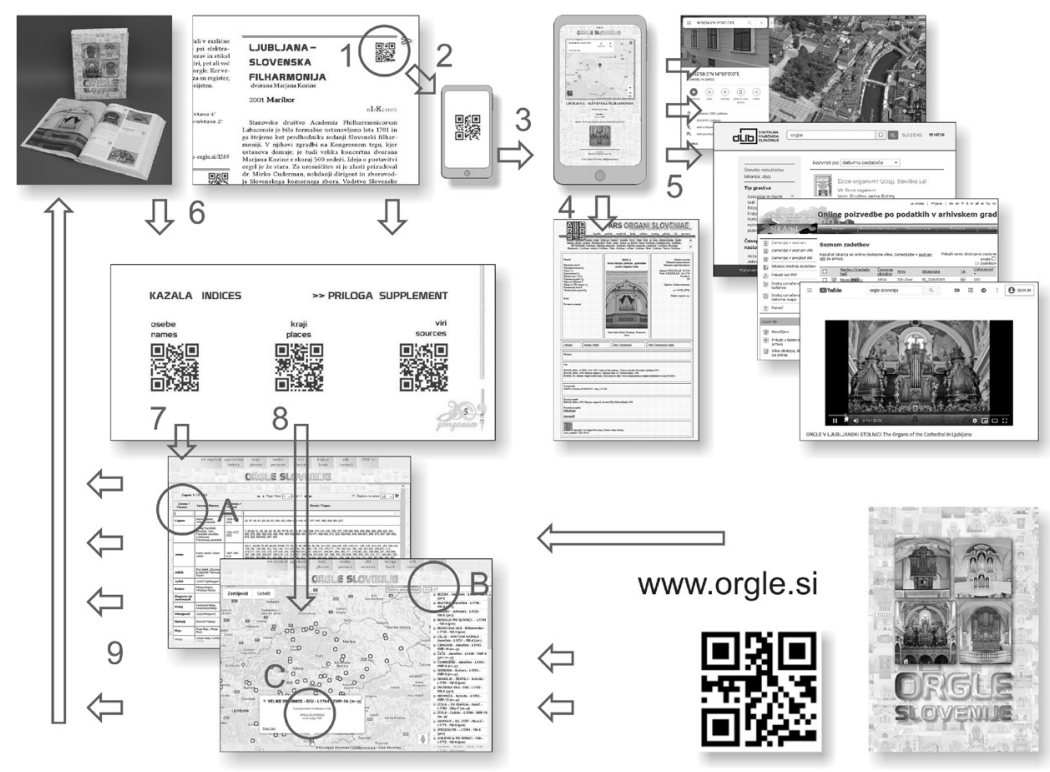

Figure 1: Interconnections between the printed book Orgle Slovenije (Pipe Organs of Slovenia) (2018) and the website www.orgle.si. See explanation in paragraphs 3.10 and 4.1. 
instrument. The idea was not just to prolong the short life of the paper, but to upgrade the printed facts with content not suitable for a book, such as sound examples, links to scientific sources, multimedia, and so on (Figure 1:4,5). Moreover, we recognise the internet as an interactive communication tool to stimulate the networking of existing knowledge, as well as to raise awareness by involving our audience in the debate about organs and their importance as heritage, art and music.

\section{Results, discussion and application}

Every catalogue or database has its own structure and holds specific elements, which depend on the scope and aim of the survey. What makes the results most reliable, however, is the quality of the data. When we speak of data collected for social sciences, we hardly ever expect homogeneity or prior standards. In research, in order to achieve a trustworthy summary, we should therefore at least tend towards the best structure possible.

In the study of the organ as a mechanical and acoustic instrument, one cannot, of course, speak of social science data in a strict sense. In an overview of the organ landscape and its characteristics, however, the broader social context is unavoidable. It provides reasons for historical development and interconnectedness, and even for particular technical solutions or trends of development or regression.

Most of the seventy catalogues discussed here share typical elements, such as location, description and particularities. Other elements, such as tables, charts, photos and multimedia, have generally emerged along with new methods and technical capabilities. In the following sections, we shall discuss the accuracy, and particularly the development and advantages, of separate core elements of the listed catalogues.

\subsection{Location}

In the opening of this paper, we introduced three overlapping categories of organological investigation: a particular instrument, a workshop and an organ landscape. To some extent, the principal elements in all three are the location(s) and the room of installation. These elements differentiate organ investigations from the study of other musical instruments.

Geography and topography create a specific backgrounded for the discussed landscape catalogues. As is evident from the titles of books and articles, the majority of works associate the organs with the administrative division of the Catholic Church. The prevailing ownership is therefore the primary reason for such a structure. Moreover, it explains the heritage of the official interconnections between civil, educational and ecclesiastic administration in the former Austro-Hungarian Monarchy, as is especially notable in surveys prior 
to the First World War. As one can see in the title of his treatise Gradivo za statistiko orgelj v ljubljanski škofiji oz. na Kranjskem (Material for Organ Statistics in the Ljubljana Diocese or in Carniola), Premrl intertwined the civil and ecclesiastic denomination. Both dioceses' surveys served as an internal inventory, as did, to some extent, the surveys by Škulj and Rola, both ordinate as priests. For the researcher today, a topographical approach demands a thorough acquaintance with the Church administrative hierarchy, the dualism of civil and parish names, and the historical topography, including translations of names into German or Italian by the contemporaneous civil or military governments. More recent problems arise regarding changed place names. For example, Nova cerkev was changed to Strmec during the communist regime but has now reverted to the original, while Šentvid was changed to Podnanos but has retained the new name.

The dynamics of place names, and sometimes their instability, is also reflected in the indexes. For example, the INDOK catalogue and the printed indexes of the recently published Pipe Organs of Slovenia were faced with the problem of where to file Sv. Jurij, Jurij, Sveti Jurij, Št. Jurij, Šentjurij, which are all slightly distinct name forms of the same village and parish near Grosuplje.

A geographic map first appeared as the most reliable solution for visualising spatial data in 1985 . The editors pointed to hundreds of organs within the simple borders of the country in the book Orgle na Slovenskem. However, many later publications have overlooked this intuitive tool. On the other hand, the ARSORS database initially proceeded from locations. The concurrent development of digital geography, particularly GIS software and relational database systems, allowed its authors to implement a comprehensive network of data, including the precise geolocation. Interactive web-based maps (Figure 1: B, C), with their diverse visualisation capabilities, are useful for simplifying research and increasing the attractiveness of education. Upto-date versions are now available as an integral part of Orgle Slovenije on the website www.orgle.si.

\subsection{Technical data}

The table or spreadsheet has been the most common form of technical data presentation over the last century. Many advantages arise from using tables, even printed ones. For example, one can recognise patterns of similarities or exceptions between listed items. Moreover, one can imagine at least the simple grouping and categorising of data in other ways than printed.

In contrast to others, Premrl formed a table for his own personal use and later internal upgrading only. While this table resulted in a brilliant research treatise by the Ljubljana Diocese expert, Austrian war officers used similar tables as the ultimate tool to requisition the parts of organs valuable for military purposes. The Lavant (Maribor) survey has survived in the text version only. 
Soon after the emergence of computers, the manipulation of data migrated to the digital environment. In the catalogues and research papers examined, however, the authors barely used the advantages offered by commercial or open-source spreadsheet software, such as summarising, criteria selection, developing charts and many other applications available since the 1980s. Only in Orgle Slovenije have the authors installed the spreadsheets on the web, making their sorting and filtering capabilities publicly available.

In the considered catalogues, authors present data in two ways: first, as an introduction to further detailed catalogue records; second and more often, as an index that substitutes a summary. Summaries have sometimes omitted critical comments, which may offer the creator's insight and help the reader to concentrate on his or her own planned research.

Stop lists (dispositions) represent a special group of technical data. From them, one can recognise the main acoustical characteristics, the size, the historical style, sometimes the authorship, the likely original state and more. In the examined material, these data are missing only in the requisition lists, and even there some survey records should exist, at least for the Diocese of Lavant. After studying and gaining experience in organology in Italy and Germany, Edo Škulj and prominent ex-Yugoslavia musicologist Ladislav Šaban fixed the standards for disposition layout. The typical layout is separated by keyboards, and starts listing the stops with the principal chorus, continuing with the concert stops such as flutes and strings and ending with reeds. Few papers written after the 1980s deviate from this scheme. However, what the artist would certainly miss is information about accessories and playing aids, which are particularly prevalent in organs of the late nineteenth century. Again, details on couplers, divisions, presets and similar devices came to light in 2018.

Data managers and advanced users would recognise the problems associated with inserting longer stop dispositions into a printed table of organ lists. Printed media avoided such couplings, while the computer-based MS-Access within the ARSORS system executed a relational database in 2005. This structured hierarchy serves for criteria sorting, filtering, preparation of multi-level pivot tables, mathematical statistics and more.

On surveying the technical data, one must not avoid the significance of the value zero; for example, the list of organs in a particular area must reveal which churches do not hold an organ. Such information differs profoundly from scientific ignorance. A scientist should consider this problem for the many instruments of high historical value that were transferred to affiliated churches and chapels in the past but are used less and less for religious services today.

\subsection{General description}

Traditionally, papers have bound their catalogues to a historical context. Although authors place the historical overview as the introduction to the treatise, 
in most instances it actually represents the time-oriented conclusion of the catalogue.

The examples from most organ catalogues around the world, including the Lavant Survey and Premrl's Statistika, represent models for the textual parts of descriptions. In some of the catalogues discussed, the organ description repeats technical data as a free text. If not efficiently commented, such wording fails to bring any significant value to science. Similarly, information on the social events connected with the organs in question mostly burdens organologists and only adds possible value for lay readers. Some of the catalogues, such as Škulj's survey in 1987 and Pirih's survey a decade later, omit description altogether. For Skulj and certain other musicologists and historians, however, description served them well for their subsequently published scientific articles.

\subsection{Graphics}

Scattered graphic portrayals of organs appeared in the second half of the nineteenth century. Later, Franc Kimovec, an organ expert of the Ljubljana Diocese, enthusiastically photographed organs designed by the prominent Modern Style architect Ivan Vurnik and constructed by the Janko workshop. Newspapers rarely published organs before the First World War.

In 1935, Rafko Fabiani was the first to systematically insert photographs in his catalogue of organs in Ljubljana. Musicologists and enthusiasts had to wait half a century for the next publication of graphics, probably due to the political regime repressing all kinds of religiously oriented research. Professional photographers enhanced the descriptions and data of the book Orgle na Slovenskem, as of Bach's year of 1985, with outstanding facade photos, but few details. Edo Škulj and Milko Bizjak, the authors of the book's texts, later occasionally inserted graphics along with their articles. In contrast, Marjan Rola took photos with many details of scientific value during his field survey in the 1990s. Recently, Katarina Trček has collected her own photographic material to support the results of her dissertation.

Surprisingly, art historians and heritage officers have mostly neglected organs when describing the interiors of religious buildings or analysing the value of wooden structures installed. Only in 2015 did Boštjan Roškar and Tatjana Štefanič from the Ptuj Museum publish a systematic catalogue of facades made by Jan Frančišek Janeček, ${ }^{11}$ a highly acknowledged late-Baroque master of Czech origin, active in Slovenia and Croatia. In 2017, the German professional journal Acta organologica presented the results of outstanding Modern Style facades in Slovenia. ${ }^{12}$

11 Tatjana Štefanič and Boštjan Roškar, "Tipologija ohranjenih ohišij glasbil Janeza Frančiška Janečka na območju Slovenije," in Celjski baročni orglarski mojster Janez Frančišek Janeček, ed. Tatjana Štefanič (Ptuj: Pokrajinski muzej Ptuj - Ormož, 2016), 109-196.

12 Jurij Dobravec “Orgelprospekte im 'Modern Style' in Slowenien," Acta Organologica 35 (2017): 223-267. 


\subsection{Audio and multimedia}

Many older recordings exist in the archives of radio and TV houses, but video and audio recording for organological research commenced after 2000. Other catalogues with multimedia presentations emerged only with the onset of the digital era, along with digital desktop publishing and progress in computer capacities. As mentioned above, organologists began dealing with maps in the 1970s. Again, only computer technology and the internet made interactive online maps easily and freely available for researchers and enthusiasts. For example, a sequence of maps joined into a one-minute video offers a visual representation of the historical spread of organs at www.orgle.si. Backed by reliable data, this kind of timeline presentation goes beyond mere curiosity and becomes a genuine scientific tool. Systematically taken photographs are similarly served. In this regard, Orgle Slovenije surpassed the catalogues by including the images of instruments from throughout Slovenia, without exception. In this way, the national organ landscape not only gained a basis for future research in architecture, design and art history, but also the ability to compare the authorship and stylistic assessments of organs.

\section{Conclusions}

In his Lexicon of Organs and their Builders, ${ }^{13}$ Edo Škulj begins his overview of Slovenian organography with Frančišek Ksaver Križman. In 1780, this prominent Baroque master of Slovenian origin critically analysed the organs in the Ljubljana cathedral and proposed his own ideas for the future. Historians consider his papers Crisi and Sistema as the dawn of Slovenian organology. As Škulj reports, in subsequent centuries, many authors followed Križman and contributed their knowledge to this social-science discipline and to the country, which synergised the organ building style of Central Europe and Venice. ${ }^{14}$ Cerkveni glasbenik played an extraordinary role in this regard, not just as a professional journal of Slovenian church musicians, but also as the oldest national periodical in the field.

Škulj refers to ARSORS as the latest chapter of the Slovenian organographic story. ${ }^{15}$ Indeed, its comprehensive complex of information offers scientists a range of possibilities for advanced analyses, comparisons, syntheses and applications. The book Orgle Slovenije, in conjunction with the website www. orgle.si, represents the first encyclopaedic offspring available to professionals, performers and enthusiasts. Its network of digital and printed information not only reflects the Slovenian organ landscape today, but also embodies its social, technical, spiritual and musical tradition.

13 Edo Škulj, "Organografija na Slovenskem," in Leksikon orgel in orglarjev (Župnija Škocjan pri Turjaku, 2013), 154-160.

14 Edo Škulj, “Tri sinteze Križmanovih orgel,” Muzikološki zbornik 51, no. 1 (2015): 81-95.

15 Škulj, “Organografija na Slovenskem,” 160. 


\section{Bibliography}

Bizjak, Milko, and Škulj, Edo. Orgle na Slovenskem [Pipe organs in Slovenia]. Ljubljana: Državna založba Slovenije, 1987.

Dobravec, Jurij. “Orgelprospekte im 'Modern Style' in Slowenien.” Acta Organologica 35 (2017): 223-267.

Dobravec, Jurij. "Presečni arhiv in zbirka podatkov o slovenskih orglah ARSORS." Arbivi 39, no. 2 (2016): 263-275.

Dobravec, Jurij. "Usoda slovenskih orgel v prvi svetovni vojni." Arbivi 41 (2017): 415-435.

Snyder, J. Kerala, ed. The Organ as a Mirror of Its Time. Oxford: Oxford University Press, 2002.

Pape, Uwe. “Orgeldatenbank." Ars Organi 34 (1986): 22-29.

Podstenšek, Matej. “Ob 100-letnici knjižice Orgle v cerkvah Lavantinske škofije.” Cerkveni glasbenik [Church musician] 104, no. 6 (2011): 11-14.

Rola, Marijan. "Orgle v mariborski dekaniji.” Bachelor's thesis, Faculty of Theology in Ljubljana, department Maribor, 1989.

Škulj, Edo. "Orgle v ljubljanski nadškofiji - 30 let pozneje.” Cerkveni glasbenik [Church musician] 111, no. 1 (2018): 13.

Škulj, Edo. "Stoletnica Premrlove Statistike o orglah v ljubljanski škofiji." Cerkveni glasbenik [Church musician] 110, no. 4 (2017): 16-17.

Škulj, Edo. “Organografija na Slovenskem.” In Leksikon orgel in orglarjerv, 154-160. Škocjan pri Turjaku, 2013.

Škulj, Edo. “Tri sinteze Križmanovih orgel.” Muzikološki zbornik 51, no. 1 (2015): 81-95.

Štefanič, Tatjana, and Boštjan Roškar. "Tipologija ohranjenih ohišij glasbil Janeza Frančiška Janečka na območju Slovenije.” Celjski baročni orglarski mojster Janez Frančišek Janeček, edited by Tatjana Štefanič, 109-196. Ptuj: Pokrajinski muzej Ptuj - Ormož, 2016.

Trček Marušič, Katarina. "Orgle in orgelska glasba v slovenski kulturni zgodovini do nastopa cecilijanstva.” Doctoral dissertation, University of Ljubljana, 2015.

\section{Appendix}

Catalogues of Slovenian organs listing more than ten instruments, with some exceptions. ( ${ }^{1}$ number of places listed, including instruments made by Slovenian masters abroad; ${ }^{2} \mathrm{SLO}$ - Slovenia, $\check{\mathrm{S}}$ - area of the separate diocese, $\mathrm{O}$ - organ building workshop, $\mathrm{R}$ - region, district or municipality, Z - exterritorial places with organs by Slovenian masters, $\check{C}$ - catalogue limited to style or period, excp. - exception with less than ten organs; * applied working title).

\begin{tabular}{lrrl}
\hline $\begin{array}{l}\text { author(s) } \\
\text { anon. }\end{array}$ & year $\begin{array}{l}\text { no. of } \\
\text { places }^{1}\end{array}$ & area & title \\
\hline Kos, Avguštin & 1911 & $300 \check{S}$ & $\begin{array}{l}\text { Orgle v cerkvah Lavantinske škofije. Maribor, } \\
1911 .\end{array}$ \\
\hline anon. & 1917 & 466 Š & $\begin{array}{l}\text { "Popis cerkvenih orgel v cerkvah mestne } \\
\text { Ljubljana. Arhiv Slovenije, AS1100. }\end{array}$ \\
\hline
\end{tabular}




\begin{tabular}{|c|c|c|c|}
\hline author(s) & year & 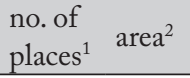 & title \\
\hline anon. & 1917 & $422 \check{S}$ & $\begin{array}{l}\text { *Seznam orgel za odvzem piščali - Lavantinska } \\
\text { škofjja. Nadškofijski arhiv Maribor. }\end{array}$ \\
\hline anon. & 1917 & $55 \check{S}$ & $\begin{array}{l}\text { *Seznam orgel za odvzem piščali - škofija Gorica. } \\
\text { Arhiv Slovenije, AS55. }\end{array}$ \\
\hline Premrl, Stanko & 1923 & $422 \check{S}$ & $\begin{array}{l}\text { "Nekoliko statistike o orgljah v ljubljanski } \\
\text { škofiji." Cerkveni glasbenik } 41 \text { (1918): 12-16, } \\
\text { 25-28, 55-58, 70-74; } 42 \text { (1919): 6-10, 21-25, } \\
\text { 33-38; 43 (1920): 54-56; "Nekoliko podrobnih } \\
\text { zanimivosti o orglah v ljubljanski škofiji." } \\
\text { Cerkveni glasbenik } 46 \text { (1923): 7-10. }\end{array}$ \\
\hline Fabiani, Rafko & 1935 & $22 \mathrm{R}$ & $\begin{array}{l}\text { "Orgle v ljubljanskih cerkvah, zgodovinsko- } \\
\text { statistična studija." Kronika slovenskib mest } 2 / 2 \\
(1935): 163-170 ; 2 / 3: 210-214 ; 2 / 4: 270-274 .\end{array}$ \\
\hline Lavrič, Anton & 1937 & 6 excp. & $\begin{array}{l}\text { “Orgle v župniji Škocijan pri Mokronogu na } \\
\text { Dolenjskem.” Cerkveni glasbenik } 60 \text { (1937): } \\
\text { 157-60. }\end{array}$ \\
\hline Rebolj, Zofija & 1944 & $29 \mathrm{R}$ & $\begin{array}{l}\text { "Ljubljanske orgle, njih zgodovina in sedanje } \\
\text { stanje."Bachelor's thesis, Ljubljana, } 1944 .\end{array}$ \\
\hline $\begin{array}{l}\text { Eberstaller, } \\
\text { Oskar }\end{array}$ & 1955 & $96 \mathrm{Z}$ & $\begin{array}{l}\text { Orgeln und Orgelbauer in Österreich. } \\
\text { (Manuskript 1929) Graz-Köln } 1955 .\end{array}$ \\
\hline $\begin{array}{l}\text { Radole, } \\
\text { Giuseppe }\end{array}$ & 1969 & $19 \mathrm{Z}$ & L'Arte organaria in Istria. Bologna, 1969. \\
\hline $\begin{array}{l}\text { Paroni, Igino } \\
\text { and Barbina, } \\
\text { Onorio }\end{array}$ & 1973 & $12 \mathrm{Z}$ & Arte organaria in Friuli. Udine, 1973. \\
\hline Caruana, Iris & 1973 & $9 \mathrm{Z}$ & $\begin{array}{l}\text { L'Arte degli organi nel Friuli Venezia Giulia- } \\
\text { Gorizia. Bologna, } 1973 .\end{array}$ \\
\hline $\begin{array}{l}\text { Radole, } \\
\text { Giuseppe }\end{array}$ & 1975 & $19 \mathrm{Z}$ & L'Arte organaria a Trieste. Bologna, 1975. \\
\hline Kilian, Szigeti & 1978 & $3 \mathrm{R}$ & $\begin{array}{l}\text { Régi magyar orgonák, Szombathely. Budapest, } \\
1978 .\end{array}$ \\
\hline Šaban, Ladislav & 1980 & $153 \mathrm{Z}$ & $\begin{array}{l}\text { Orgulje slovenskih graditelja u Hrvatskoj. Rad } \\
\text { JAZU } 385 \text { (1980): 5-84. }\end{array}$ \\
\hline $\begin{array}{l}\text { Bizjak, Milko \& } \\
\text { Škulj, Edo }\end{array}$ & 1985 & 100 SLO & $\begin{array}{l}\text { Orgle na Slovenskem. DZS Ljubljana,1985. } \\
\text { English and German version in 1987. (selected } \\
\text { instruments) }\end{array}$ \\
\hline $\begin{array}{l}\text { Benedikt, } \\
\text { Wolfgang }\end{array}$ & 1985 & $9 \mathrm{Z}$ & $\begin{array}{l}\text { "Die Orgeln der Bezirke Klagenfurt - Land } \\
\text { und Feldkirchen." Dissertation, Philosophische } \\
\text { Fakultät, Univ. Wien } 1985 .\end{array}$ \\
\hline $\begin{array}{l}\text { Trebuch, } \\
\text { Bernhard }\end{array}$ & 1986 & $14 \mathrm{Z}$ & $\begin{array}{l}\text { "Orgeln und Orgelbau im Bezirk St. } \\
\text { Veit/Glan (Kärnten).” Dissertation, } \\
\text { Geisteswissenschaftliche Fakultät, Univ. Wien } \\
\text { 1986. }\end{array}$ \\
\hline
\end{tabular}




\begin{tabular}{|c|c|c|c|}
\hline author(s) & year & $\begin{array}{l}\text { no. of } \\
\text { places }^{1}\end{array}$ area $^{2}$ & title \\
\hline Škulj, Edo & 1987 & $356 \check{S}$ & $\begin{array}{l}\text { Orgle v Ljubljanski nadškofiji. Knjižnica } \\
\text { Cerkvenega glasbenika. Zbirka 5, Knjižna } \\
\text { zbirka zv. } 3 \text {. }\end{array}$ \\
\hline anon. & 1989 & 897 SLO & $\begin{array}{l}\text { Ministry of Culture, INDOK Information } \\
\text { Center. }\end{array}$ \\
\hline Rola, Marijan & 1990 & $34 \mathrm{R}$ & $\begin{array}{l}\text { "Orgle v mariborski dekaniji." Cerkveni } \\
\text { glasbenik } 83 \text { (1990): 41-45; 67-73. }\end{array}$ \\
\hline $\begin{array}{l}\text { Jedrlinič, Alda } \\
\text { and Komel, } \\
\text { Zdenka } \\
\end{array}$ & 1990 & $10 \mathrm{O}$ & $\begin{array}{l}\text { "Ivan Kacin (1884-1953) - orglar in Paul J. } \\
\text { Šifler (r. 1911) - skladatelj, organist." Bachelor's } \\
\text { thesis, University of Ljubljana, 1990. }\end{array}$ \\
\hline $\begin{array}{l}\text { Špendov, } \\
\text { Vendelin }\end{array}$ & 1992 & $4 \mathrm{Z}$ & $\begin{array}{l}\text { "Orgle v slovenskih cerkvah v ZDA." Cerkveni } \\
\text { glasbenik } 85 \text { (1992): 23-25. (Slovenian diaspora } \\
\text { in the U.S.A.) }\end{array}$ \\
\hline Rola, Marijan & 1993 & $356 \mathrm{R}$ & $\begin{array}{l}\text { *orgle po dekanijah Mariborske škofije } \\
\text { (manuscript) }\end{array}$ \\
\hline Škulj, Edo & 1994 & $29 \mathrm{R}$ & Orgle v Ljubljani. Mohorjeva Celje, 1994. \\
\hline Pirih, Vladimir & 1995 & $109 \check{S}$ & *dispozicije orgel v Koprski škofiji (manuscript) \\
\hline Škulj, Edo & 1999 & $50 \mathrm{O}$ & $\begin{array}{l}\text { Ob desetletnici Škofijske orglarske delavnice. } \\
\text { Maribor, } 1999 .\end{array}$ \\
\hline Škulj, Edo & 1999 & $26 \mathrm{R}$ & $\begin{array}{l}\text { “Orgle v dekaniji Škofja Loka.” Loški razgledi } \\
45 \text { (1998): 73-128; } 46 \text { (1999): 285-336. }\end{array}$ \\
\hline Pisar, Valerija & 1999 & $24 \mathrm{R}$ & $\begin{array}{l}\text { "Orgle na slovenskem Koroškem." Bachelor's } \\
\text { thesis. University of Maribor, } 1999 .\end{array}$ \\
\hline Škrabl, Anton & 2000 & $90 \mathrm{O}$ & $\begin{array}{l}\text { Zvoki in harmonija. Orglarstvo Škrabl, } \\
\text { Brestovec, } 2000 .\end{array}$ \\
\hline Novak, Peter & 2000 & $28 \mathrm{R}$ & $\begin{array}{l}\text { "Orgle v dekaniji Radovljica." Bachelor's thesis, } \\
\text { University of Maribor, } 2000 .\end{array}$ \\
\hline $\begin{array}{l}\text { Malavašič, } \\
\text { Primož } \\
\end{array}$ & 2000 & $17 \mathrm{R}$ & $\begin{array}{l}\text { "Orgle v dekaniji Vrhnika." Bachelor's thesis, } \\
\text { University of Ljubljana, } 2000 .\end{array}$ \\
\hline Škulj, Edo & 2000 & $17 \mathrm{R}$ & $\begin{array}{l}\text { "Orgle v dekaniji Kamnik." Kamniški zbornik } \\
15 \text { (2000): 86-106. }\end{array}$ \\
\hline $\begin{array}{l}\text { Korošec, Josip } \\
\text { et al. }\end{array}$ & 2000 & $7 \check{C}$ & $\begin{array}{l}\text { Kulturne poti } 2000 \text { - Baročne orgle. Ministrstvo } \\
\text { za kulturo, Uprava R. Slovenije za kulturno } \\
\text { dediščino. (heritage view) }\end{array}$ \\
\hline Škulj, Edo & 2001 & $225 \mathrm{O}$ & Jenkova orglarska delavnica. Ljubljana, 2001. \\
\hline $\begin{array}{l}\text { Sevšek (de } \\
\text { Costa), Barbara }\end{array}$ & 2002 & $20 \mathrm{O}$ & $\begin{array}{l}\text { "Alois Hörbiger und sein Einfluss auf die } \\
\text { slowenische Orgellandschaft." Bachelor's thesis, } \\
\text { The University of Music and Performing Arts } \\
\text { Graz, } 2002 \text {. }\end{array}$ \\
\hline Rožanc, Suzana & 2003 & $34 \mathrm{R}$ & $\begin{array}{l}\text { "Orgle v dekaniji Šmarje pri Jelšah." Bachelor’s } \\
\text { thesis, University of Maribor, } 2003 .\end{array}$ \\
\hline Škulj, Edo & 2004 & $66 \mathrm{O}$ & Goršičeva orglarska delavnica. Ljubljana, 2004. \\
\hline
\end{tabular}




\begin{tabular}{|c|c|c|c|c|}
\hline author(s) & year & $\begin{array}{l}\text { no. of } \\
\text { places }^{1}\end{array}$ & $\operatorname{area}^{2}$ & title \\
\hline Fendre, Petra & 2004 & 29 & $\mathrm{R}$ & $\begin{array}{l}\text { "Orgle v dekanijah Celje in Žalec." Bachelor's } \\
\text { thesis, University of Maribor, } 2004 .\end{array}$ \\
\hline Lipuš, Špela & 2004 & 28 & $\mathrm{R}$ & $\begin{array}{l}\text { "Orgle v dekaniji Gornji Grad." Bachelor's } \\
\text { thesis, University of Maribor, } 2004 .\end{array}$ \\
\hline Švigelj, Ana & 2004 & 16 & $\mathrm{R}$ & $\begin{array}{l}\text { "Orgle v dekaniji Cerknica." Bachelor's thesis, } \\
\text { University of Maribor, } 2004 .\end{array}$ \\
\hline $\begin{array}{l}\text { Đerković, } \\
\text { Magda }\end{array}$ & 2005 & 49 & $\mathrm{O}$ & $\begin{array}{l}\text { "Brandlova orglarska delavnica." Bachelor's } \\
\text { thesis, University of Maribor, } 2005 .\end{array}$ \\
\hline Semler, Mateja & 2007 & 39 & $\mathrm{R}$ & $\begin{array}{l}\text { "Orgle v Prekmurju." Bachelor's thesis, } \\
\text { University of Maribor, } 2007 .\end{array}$ \\
\hline Škulj, Edo & 2007 & 39 & $\mathrm{O}$ & Milavčeva orglarska delavnica. Ljubljana, 2007 \\
\hline $\begin{array}{l}\text { Emeršič } \\
\text { (Oblonšek), } \\
\text { Cecilija }\end{array}$ & 2007 & 32 & $\mathrm{R}$ & $\begin{array}{l}\text { "Orgle v dekanijah Ptuj in Zavrč.” Bachelor's } \\
\text { thesis, University of Maribor, } 2007 .\end{array}$ \\
\hline Majcen, Jana & 2007 & 23 & $\mathrm{R}$ & $\begin{array}{l}\text { "Orgle v dekanijah Nova Cerkev in Slovenske } \\
\text { Konjice.” Bachelor's thesis, University of } \\
\text { Maribor, } 2007 .\end{array}$ \\
\hline $\begin{array}{l}\text { Kirbiš, } \\
\text { Aleksandra }\end{array}$ & 2007 & 16 & $\mathrm{R}$ & $\begin{array}{l}\text { "Orgle v dekaniji Dravsko polje." Bachelor's } \\
\text { thesis, University of Maribor, } 2007 .\end{array}$ \\
\hline Škulj, Edo & 2009 & 125 & $\mathrm{O}$ & Zupanova orglarska delavnica. Škocjan, 2009. \\
\hline Škulj, Edo & 2009 & 46 & $\mathrm{O}$ & Naraksova orglarska delavnica. Škocjan, 2009. \\
\hline Škulj, Edo & 2009 & 38 & $\mathrm{O}$ & $\begin{array}{l}\text { Mayerjeva orglarska delavnica (Mayer, } \\
\text { Mauracher, Rieger). Škocjan, } 2009 .\end{array}$ \\
\hline Jezernik, Anja & 2009 & 35 & $\mathrm{R}$ & $\begin{array}{l}\text { "Orgle v dekanijah Braslovče in Šaleška dolina." } \\
\text { Bachelor's thesis, University of Maribor, } 2009 .\end{array}$ \\
\hline Škulj, Edo & 2010 & 245 & $\mathrm{O}$ & $\begin{array}{l}\text { Škrablova orglarska delavnica. Orglarstvo Škrabl, } \\
\text { Brestovec } 2010 .\end{array}$ \\
\hline $\begin{array}{l}\text { Allmer, } \\
\text { Gottfried et al. }\end{array}$ & 2010 & 30 & $\mathrm{O}$ & $\begin{array}{l}\text { Alois Hörbiger (1810-1876), der Orgelbauer von } \\
\text { Tirol. Wildschönau Bergbauernmuseum z' } \\
\text { Bach, } 2010 .\end{array}$ \\
\hline Škulj, Edo & 2010 & 20 & $\mathrm{O}$ & Križmanova orglarska delavnica. Ljubljana, 2010. \\
\hline Škulj, Edo & 2011 & 101 & $\mathrm{O}$ & $\begin{array}{l}\text { Rumplova orglarska delavnica (Rumpel, } \\
\text { Mandlin, Pevec, Papa, Račič). Škocjan, } 2011 .\end{array}$ \\
\hline Škulj, Edo & 2012 & 136 & $\mathrm{O}$ & $\begin{array}{l}\text { Baročne orglarske delavnice (Faller, Wallenstein, } \\
\text { Pauhaus, Steinoffer, Göbl, Eißl, Kučera, Janeček, } \\
\text { Scholtz, Martl, Otonič). Škocjan, 2012. }\end{array}$ \\
\hline Škulj, Edo & 2012 & 76 & $\mathrm{O}$ & $\begin{array}{l}\text { Goriške orglarske delavnice (Kacin, Valiček, Bencz, } \\
\text { Kucler, Zitzman in Ježek). Škocjan, 2012. }\end{array}$ \\
\hline $\begin{array}{l}\text { Isenberg, } \\
\text { Gabriel }\end{array}$ & $\begin{array}{l}\text { until } \\
2012\end{array}$ & 35 & $\mathrm{Z}$ & www.orgelsammlung.de (website) \\
\hline Cej, Uroš & 2012 & 32 & $\mathrm{O}$ & $\begin{array}{l}\text { "Orglarska delavnica Ivana Kacina in njegovi } \\
\text { sodobniki med obema vojnama.” Bachelor's } \\
\text { thesis, University of Ljubljana, } 2012 \text {. }\end{array}$ \\
\hline
\end{tabular}




\begin{tabular}{|c|c|c|c|c|}
\hline author(s) & year & $\begin{array}{l}\text { no. of } \\
\text { places }^{1}\end{array}$ & $\operatorname{area}^{2}$ & title \\
\hline Heinz, Otmar & 2012 & 12 & $\check{C}$ & $\begin{array}{l}\text { Frübbarocke Orgeln in der Steiermark. Wien; } \\
\text { Münster; Lit, cop. } 2012 .\end{array}$ \\
\hline Škulj, Edo & 2013 & 46 & $\mathrm{O}$ & $\begin{array}{l}\text { Malahovskega orglarska delavnica. Škocjan, } \\
\text { 2013. }\end{array}$ \\
\hline Škulj, Edo & 2013 & 40 & $\mathrm{O}$ & $\begin{array}{l}\text { Beneška orglarske delavnice (Collona, Carloni, } \\
\text { Nakić, Callido, Bossi, Marlini, de Corte, Tonoli, } \\
\text { Zanin, Pugina, Mascioni, Aletti). Škocjan, } \\
2013 .\end{array}$ \\
\hline Škulj, Edo & 2014 & 74 & $\mathrm{O}$ & $\begin{array}{l}\text { Ob 25-letnici Orglarske delavnice Maribor. } \\
\text { Maribor, } 2014 .\end{array}$ \\
\hline $\begin{array}{l}\text { Ambrožič, } \\
\text { Matjaž }\end{array}$ & 2014 & 16 & $\mathrm{R}$ & $\begin{array}{l}\text { Orgle v cerkvah Občine Lukovica. Zbornik } \\
\text { Občine Lukovica II: 100-111. }\end{array}$ \\
\hline $\begin{array}{l}\text { Trček Marušič, } \\
\text { Katarina }\end{array}$ & 2015 & 477 & SLO & $\begin{array}{l}\text { "Orgle in orgelska glasba v slovenski kulturni } \\
\text { zgodovini do nastopa cecilijanstva." Doctoral } \\
\text { dissertation, University of Ljubljana, 2015. }\end{array}$ \\
\hline Škulj, Edo & 2015 & 149 & $\mathrm{O}$ & Brandlova orglarska delavnica. Škocjan, 2015. \\
\hline Škulj, Edo & 2015 & 23 & $\mathrm{O}$ & Rojčeva orglarska delavnica. Škocjan, 2015. \\
\hline $\begin{array}{l}\text { Štefanič, } \\
\text { Tatjana et al. }\end{array}$ & 2016 & 33 & $\mathrm{O}$ & $\begin{array}{l}\text { Celjski baročni orglarski mojster Janez Frančišek } \\
\text { Janeček. Pokrajinski muzej Ptuj - Ormož, } 2016 .\end{array}$ \\
\hline Dobravec, Jurij & 2017 & 28 & $\check{\mathrm{C}}$ & $\begin{array}{l}\text { "Orgelprospekte im 'Modern Style' in } \\
\text { Slowenien." Acta Organologica } 35 \text { (2017): } \\
\text { 223-267. }\end{array}$ \\
\hline $\begin{array}{l}\text { Škulj, Edo and } \\
\text { Dobravec, Jurij }\end{array}$ & 2018 & 1094 & SLO & Orgle Slovenije. Jarina Bohinj, 2018. \\
\hline $\begin{array}{l}\text { Dobravec, Jurij, } \\
\text { and Mikelj, } \\
\text { Kristina }\end{array}$ & current & 2900 & $\begin{array}{l}\mathrm{SLO} \\
+\mathrm{Z}\end{array}$ & $\begin{array}{l}\text { ARSORS - Ars organi Sloveniae (database); } \\
\text { Jarina Bohinj Association }\end{array}$ \\
\hline $\begin{array}{l}\text { Feinig, Andrej, } \\
\text { and Dobravec, } \\
\text { Jurij }\end{array}$ & current & 270 & $\begin{array}{l}\text { SLO } \\
+Z\end{array}$ & $\begin{array}{l}\text { Orgle slovenskih izdelovalcev na Koroškem; } \\
\text { Jarina Bohinj Association }\end{array}$ \\
\hline
\end{tabular}

\section{POVZETEK}

\section{Raziskave slovenskih orgel od začetka 20. stoletja do monografije Orgle Slovenije leta 2018}

Sistematični regionalni ali tematski popisi orgel na Slovenskem segajo v začetek 20. stoletja. V Lavantinski (Mariborski) škofiji je skupina strokovnjakov popis orgel pripravila leta 1911. V Ljubljanski škofiji je podatke zbral in nekaj let kasneje predstavil Stanko Premrl. Oba zapisa poleg uvodnih razlag vsebujeta glavni del v obliki kataloga vseh popisanih orgel z nekaj osnovnimi podatki. Pri obeh 'statistikah' je na osnovi kataloga bil pripravljen zbirni prikaz v obliki vezanega besedila, deloma tudi vrednotenje. Sistematično delo se je v večjem 
obsegu nadaljevalo v osemdesetih letih 20. stoletja, ko je izšla knjiga Orgle na Slovenskem z izborom 100 'najpomembnejših' orgel. Popise je od leta 1987 naprej izvajal predvsem Edo Škulj. Poleg lastnega dela so po isti metodi popisovali njegovi študenti in študentke ter nekateri drugi sodelavci. Pri statističnih pregledih se je uveljavil tabelarični prikaz z različnimi razporeditvami podatkov, npr. po času izdelave, številki opusa ali lokaciji. Štajersko je popisal Marjan Rola. Leta 2005 so v Društvu Jarina Bohinj vzpostavili podatkovno zbirko Ars organi Sloveniae, od leta 2018 pa so podatki o vseh obstoječih orglah v Sloveniji zbrani v monografiji Orgle Slovenije.

Podatkovna osnova monografiji Orgle Slovenije je podatkovni sistem Ars organi Sloveniae. Ta vsebuje podatke o vseh znanih orglah, ki so doslej stale v Sloveniji in so jih izdelali slovenski orglarji po svetu. Strukturirana podatkovna zbirka je organizirana na treh ravneh: [1] na spletu dostopni seznami in karte, [2] interna relacijska podatkovna baza za trenutno 2900 orgel, in [3] skladišče virov, kjer je trenutno shranjenih okrog 16.000 različnih dokumentov in več kot 54.000 fotografij. $V$ podatkovnem sistemu se za vsake orgle vodi 65 parametrov, kar omogoča različne analize, statistične obdelave in grafične prikaze.Vsak dosedanji popis vsebuje statistični pregled. Ti temeljijo na različnih strukturah osnovnih podatkov in se medsebojno razlikujejo po obliki, uporabnosti in sporočilnosti. $\mathrm{V}$ preglednem prispevku je prikazano, kako so se v nekaj več kot 100 letih metode dela dopolnjevale in kako so različne strukture podatkov omogočale različne prikaze ter različno uporabo za organološko raziskovalno delo.

\section{ABOUT THE AUTHOR}

JURIJ DOBRAVEC (jurij.dobravec@jarina.org,www.jurij.dobravec.si) graduated from the University of Ljubljana in biology in 1993. During his university studies, he attended the Ljubljana Organists School for four years, studying music history and organology in the class of Professor Edo Škulj. Later, in parallel with managing the Science and Research Department at the Triglav National Park administration, he did voluntary work as a choir conductor and church organist, and in 2005 he established a national organ database managed by the non-governmental institute Ars organi Sloveniae. In 2018, in co-authorship with Dr Škulj, this comprehensive data system was summarised in an innovative complex in the printed book Pipe Organs of Slovenia and the website www.orgle.si. In addition to other activities, Dobravec contributed the Slovenian entry for the international Organ Dictionary, published in 2015 in 23 languages, while his articles on the organ and the results of musicology research have appeared in professional publications such as Acta organologica, Cerkveni glasbenik, Arhivi, Informazione organistica, Varstvo spomenikov, Ars Organi, ISO journal, Ecce organvm! and others.

\section{O AVTORJU}

JURIJ DOBRAVEC (jurij.dobravec@jarina.org, www.jurij.dobravec.si) je leta 1993 diplomiral iz biologije na Univerzi v Ljubljani. med študijem je obiskoval ljubljansko Orglarsko šolo, kjer je zgodovino glasbe in organografijo poslušal pri prof. Edu Škulju. Vzporedno s službo v javnem zavodu Triglavski narodni park, kjer je vodil Znanstveno raziskovalni oddelek, je prostovoljno delal kot zborovodja in cerkveni organist. Leta 2005 je zasnoval nacionalno zbirko podatkov o orglah ARSORS in neprofitni inštitut Ars organi Sloveniae v okviru Društva Jarina Bohinj. Leta 1918 je v soavtorstvu z Edom Škuljem svoje znanje in sposobnosti združil v inovativno publikacijo tiskane knjige Orgle Slovenije in spletne strani www. 
orgle.si. Poleg aktivnosti na svojem primarnem biološkem področju, je Dobravec prispeval slovenski prevod v mednarodni 23-jezični Orgelski slovar, ki je 2015 izšel v Belgiji, poglavje znanstvene monografije o celjskem orglarju J. F. Janečku. Njegovi članki s področja orgel, glasbe in muzikologije, skupaj 160, so bili objavljeni v domačih in mednarodno priznanih znanstvenih in strokovnih revijah Acta organologica, Cerkveni glasbenik, Arbivi, Informazione organistica, Varstvo spomenikov, Ars Organi in ISO journal. Od 2015 ureja orglam posvečeno slovensko revijo Ecce organvm! 